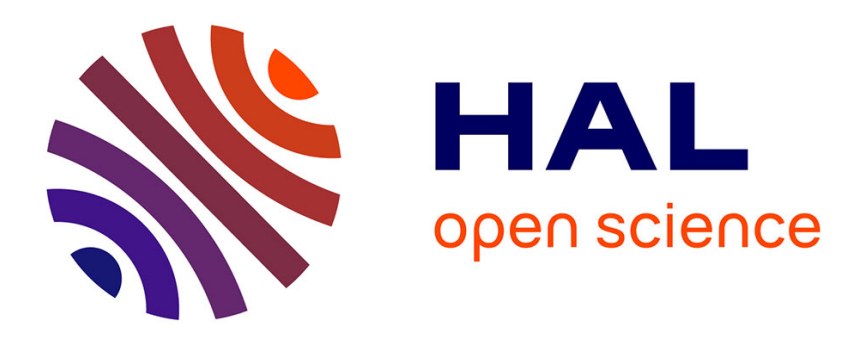

\title{
CO2 baseline concept in 3-D atmospheric transport models
}

\author{
M. Ramonet, P. Monfray
}

\section{To cite this version:}

M. Ramonet, P. Monfray. CO2 baseline concept in 3-D atmospheric transport models. Tellus B Chemical and Physical Meteorology, 1996, 48 (4), pp.502-520. 10.3402/tellusb.v48i4.15929 . hal03115979

\section{HAL Id: hal-03115979 \\ https://hal.science/hal-03115979}

Submitted on 21 Jun 2021

HAL is a multi-disciplinary open access archive for the deposit and dissemination of scientific research documents, whether they are published or not. The documents may come from teaching and research institutions in France or abroad, or from public or private research centers.
L'archive ouverte pluridisciplinaire HAL, est destinée au dépôt et à la diffusion de documents scientifiques de niveau recherche, publiés ou non, émanant des établissements d'enseignement et de recherche français ou étrangers, des laboratoires publics ou privés. 


\section{Tellus B: Chemical and Physical Meteorology}

\section{$\mathrm{CO}_{2}$ baseline concept in 3-D atmospheric transport models}

\section{Ramonet \& P. Monfray}

To cite this article: M. Ramonet \& P. Monfray (1996) $\mathrm{CO}_{2}$ baseline concept in 3-D atmospheric transport models, Tellus B: Chemical and Physical Meteorology, 48:4, 502-520, DOI: 10.34021 tellusb.v48i4.15929

To link to this article: https://doi.org/10.3402/tellusb.v48i4.15929

\section{(c) 1996 The Author(s). Published by Taylor \& Francis.}

\section{曲 Published online: 18 Jan 2017.}

Submit your article to this journal

山 Article views: 51

Q View related articles $\sqsubset$

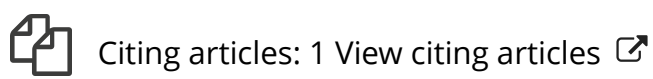




\title{
$\mathrm{CO}_{2}$ baseline concept in 3-D atmospheric transport models
}

\author{
By M. RAMONET* \\ CEA, Avenue de la Terrasse, F91198 Gif sur Yvette Cédex, France
}

(Manuscript received 10 July 1995; in final form 22 May 1996)

\begin{abstract}
Atmospheric transport models are now commonly used to estimate the distribution of sources and sinks of $\mathrm{CO}_{2}$, given atmospheric measurements of this greenhouse gas. Yet, to properly assess large-scale flux patterns, one must employ only those measurements that are representative of large scale air masses. Typically the observed time series are filtered, according to different criteria, as a mean to select baseline conditions. In this paper we raise the problem of comparing selected data with the whole simulated time series. Aiming for better consistency with the observations, we propose four procedures to select the baseline periods in the transport models. Each is tested with a high resolution 3-D model (TM2z), at 3 monitoring stations currently used by the modeling community (Cape Grim, Cape Meares, and Amsterdam Island). Results demonstrate that such selection is necessary, especially for coastal stations. By using information on the synoptic transport as estimated by either 5-days backtrajectories or radon-222 concentrations, the $\mathrm{CO}_{2}$ synoptic scale variability (averaged over the year) is reduced by a factor of three. The seasonal cycle (peak-to-peak amplitude) is also reduced by about $30 \%$ for the two coastal stations. With these corrections, the model-data agreement improves dramatically. Moreover, annual averages can be affected by few tenths of ppmv. Finally, we also investigate synoptic events classified as non-baseline both in observations and simulations. The ability of the 3-D model to reproduce some characteristics of these data, points out the potential of such data to characterize the strength of regional fluxes.
\end{abstract}

\section{Introduction}

During the last decade, considerable progress have been made in the comprehension of the global and regional carbon cycle thanks to the monitoring network of $\mathrm{CO}_{2}$ mixing ratio, and its interpretation through atmospheric transport models (Keeling et al., 1989; Tans et al., 1989, 1990; Enting and Mansbridge, 1989, 1991; Enting et al., 1993, Conway et al., 1994a; Ciais et al., 1995). The monitoring network was first designed to account for the North/South gradient. However, the growing number of observatories (Tanaka et al., 1987; WMO/WDCGG, 1992;

* Corresponding author.

E-mail: mramonet@cmdl.noaa.gov

‡Present Affiliation: CMDL/NOAA, Boulder, Co, USA.
Conway et al., 1994b) is now intended to represent the large-scale (i.e., some thousands of $\mathrm{km}$ ) features of the atmospheric $\mathrm{CO}_{2}$ distribution. Then, the aim of this network is to get enough information to characterize the major ocean circulation and terrestrial biomes features, by using a 3-D atmospheric transport model.

To be of interest for $\mathrm{CO}_{2}$-modeling on the large scale, the atmospheric $\mathrm{CO}_{2}$ measurements must fulfill two conditions: (1) to be calibrated with the worldwide monitoring network; (2) to be representative of large and horizontally well-mixed air masses. The later condition of spatial representativeness is insured by sampling the air masses during the so-called baseline periods, which exclude the periods of local contamination (human exhalation, cars or diesel generator running in the vicinity, etc.) and local respiration/photosynthesis 
of the terrestrial biota. The later contribution is a tricky problem since it represents a component of the global $\mathrm{CO}_{2}$ budget we want to pinpoint, but any modest amount of local vegetation can act as a very large source or sink (Wofsy et al., 1993; Bakwin et al., 1995). These local signatures are generally strong enough to mask any large-scale contribution. Since the space-time distribution of the surface fluxes and the atmospheric stability, are much less variable over ocean than over continents, the baseline conditions are easier to find in marine environments. For these reasons about $75 \%$ of the stations making the international network, are located on remote islands or near the coasts, emphasizing oceanic air (WMO/WDCGG, 1992).

The determination of the baseline periods is station-dependent, and it requires comprehensive studies of the station surroundings, the prevailing meteorological conditions, and the $\mathrm{CO}_{2}$ variability at the site. The most currently used criteria are: the local wind speed and wind direction, the short term $\mathrm{CO}_{2}$ variability, and measurements of other tracers such as radon-222 (Enting and Pearman, 1993). Providing that the data are intended to assess the large-scale features of the carbon cycle, and that small-scale variations are difficult to interpret, the filtering of the observational data is nothing but requisite (Enting et Pearman, 1993). The large-scale flux distribution inferred from the selected observations will depend on the quality of the model/data comparisons. Consequently it is very important to warrant the consistency of baseline observations with the calculated values. Even though the global transport model cannot resolve the local contributions, it is necessary to take into account the fact that rejecting local effects makes it often necessary to reject the continental air masses. In such a case the baseline selections introduce a bias by rejecting the regional land flux influence. So far, the only way to deal with this problem was to move the coastal sites one box off-shore, in order to decrease the influence of the continental fluxes. This method is unsatisfactory because it does not care about the origin of the air masses. Furthermore, the refinement of the transport models (horizontal and vertical resolutions, time step, parameterizations of the vertical transport) enables those models to simulate more and more accurately the specific processes over the continents, like the large $\mathrm{CO}_{2}$ increase under a nocturnal inversion layer. In the observational data, the influence of such processes are rejected, and then their occurrence in the simulated time series could strongly bias the model/data comparisons. These model refinements have been seen to be important even for largescale features of carbon cycle (Denning, 1995; Rayner et Law, 1995), but they raise new questions about the consistency of the comparisons between baseline measurements and simulated values.

In this study, we use 4 methods to select the baseline periods in the time series simulated with a 3-D transport model. The priorities for such a selection should be: (1) to reproduce the sampling done for the observations; (2) to be reliable for both marine and coastal sites; (3) to be easily implemented in the post-processing of the model results. According to these objectives, we compare the efficiencies of the four methods at 3 contrasting sites: a coastal station in Southern hemisphere (Cape Grim: $40^{\circ} 41^{\prime} \mathrm{S}, 144^{\circ} 41^{\prime} \mathrm{E} / \mathrm{CSIRO}-\mathrm{DAR}$ ); a coastal station in Northern hemisphere (Cape Meares: $45^{\circ} 29^{\prime} \mathrm{N}, 123^{\circ} 58^{\prime} \mathrm{W} / \mathrm{NOAA}-\mathrm{CMDL}$ ); and a marine station located in Austral Indian Ocean (Amsterdam Island: $37^{\circ} 47^{\prime} \mathrm{S}, 77^{\circ} 31^{\prime} \mathrm{E} / \mathrm{CNRS}-\mathrm{CEA}$ CFR). From these comparisons we quantify how the rejection of non-baseline periods in the simulated time series affects the annual means, as well as the seasonal and synoptic scale variations. Finally, we also investigate how some periods which are presently rejected could be of interest as an imprint of the continental fluxes and transport processes which occur in the surroundings (some hundreds kilometers) of the continuous monitoring sites.

\section{Methodology}

We have chosen to focus our study on the results obtained at Cape Grim, Cape Meares, and Amsterdam Island because: (1) these stations are currently used to assess the global carbon cycle; (2) we want to test the baseline selections for both coastal and marine sites; (3) problems have been raised for the $\mathrm{CO}_{2}$ simulations at these stations (Heimann et al., 1989a; Erickson et al., 1996). Prior to the discussion about the consistency of the model/data comparisons, we briefly describe the environment of the three monitoring sites, and how the simulated concentrations were calculated. 


\subsection{Environment of the three stations}

The sites and methods of the three stations were described by Beardsmore and Pearman (1987), Conway et al. (1994b), and Gaudry et al. (1983) respectively for Cape Grim, Cape Meares and Amsterdam Island. The three stations are both located along sea coast at the top of a cliff, though their regional environments are quite different (Fig. 1). Cape Grim is located on the Tasmanian coast and about $300 \mathrm{~km}$ from Australia. Cape Meares is located in Oregon on the Pacific coast. On the other hand the Amsterdam station lies on a small island $\left(55 \mathrm{~km}^{2}\right)$ in Austral Indian Ocean, far away (more than $3.000 \mathrm{~km}$ ) from any continental influence. From these three stations, Cape Meares is the only one which does not perform continuous $\mathrm{CO}_{2}$ measurements. Flasks are collected in pairs, once or twice per week, and their content is analyzed at CMDL/NOAA, Boulder (Conway et al., 1994b). Since the flask stations make the majority of the $\mathrm{CO}_{2}$ network, it is important to study the model/data comparison in such a site.

The criteria used to identify the baseline periods were defined by Beardsmore and Pearman (1987) for Cape Grim, and by Gaudry et al. (1987) for Amsterdam Island (Table 1). At Cape Meares the flasks are generally sampled in the afternoon to avoid the land breeze. Yet this precaution is not sufficient to warrant the baseline conditions. Then, a two step "a posteriori" procedure is carried out: first the bad flask pairs (difference greater than $0.5 \mathrm{ppmv}$ ) are rejected; and second the data lying more than \pm 3 residual standard deviations from a fitted curve are considered as locally contaminated (Conway et al., 1994b). The same procedure is used for all the flask stations of the CMDL/NOAA network. The three stations are parts of the Global Atmospheric Watch program (GAW), and the baseline concentrations are archived at the World Data Center for Greenhouse Gases publications (WDCGG, Tokyo/Japan), and the Carbon Dioxide Information Analysis Center (CDIAC, Oak Ridge/USA).

\subsection{The 3-D transport model, and $\mathrm{CO}_{2}$ fluxes distribution}

The 3-D transport model used in this study is derived from the model TM1 developed by Heimann et al. (1989b). Yet, the present version has been largely modified for the parameterization of the subgridscale vertical transport by convective clouds and turbulent diffusion. These two processes are now estimated according to Tiedtke (1989) and Louis (1979) schemes, which were implemented in the TM2 model by Heimann (1995). Then all the transport terms are driven by the ECMWF's uninitialised analysis values (00UTC and 12UTC) for the year 1990, interpolated to a $2.5^{\circ} \times 2.5^{\circ}$ regular latitude/longitude grid. The vertical resolution is similar to the previous model versions ( 9 levels), but we use an enhanced horizontal resolution $\left(2.5^{\circ} \times 2.5^{\circ}\right)$. This new version $\mathrm{TM} 2 z$ was motivated by our interest in the synoptic scale tracers variations (Ramonet et al., 1996). Such variations will be described in the next section.

To simulate the concentration of atmospheric $\mathrm{CO}_{2}$ with the 3-D transport model, we have defined a global distribution of the surface fluxes. This work was done in a similar way than Heimann et al. (1989b). The surface fluxes were broken up in a set of 10 components: one for the industrial source; four for the terrestrial biospheric fluxes (net primary productivity, heterotrophic respiration, deforestation, and fertilization effect); and five for the oceanic fluxes (boreal, tropical, subtropical/subantarctique, antarctic, seasonal) (Ramonet, 1994). To be coherent with the $\mathrm{CO}_{2}$ measurements and the atmospheric transport, the net fluxes have been updated for the year 1990 . Furthermore, two of them are based on new datasets. First, the net primary productivity is calculated from remote sensing NDVI for the year 1990 (Ruimy et al., 1994). Second, the oceanic fluxes between $18^{\circ} \mathrm{S}$ and the Antarctic Polar Front are estimated from $\mathrm{pCO}_{2}$ measurements over Indian and Atlantic oceans (Weiss et al., 1992; Poisson et al., 1993). The oceanic fluxes are then calculated from Liss and Merlivat (1986) relationship by using sea surface temperatures and wind fields at $10 \mathrm{~m}$ given by the ECMWF's analyses for the year 1990 .

For each of the ten components a four years run was performed with a perpetual 1990s meteorology and $\mathrm{CO}_{2}$ fluxes. Each run was started from an initial uniform zero concentration field. The hourly concentrations of the 4th model year for each component were added together. The composite time series were subsequently decomposed in: a linear trend $\left(C_{\text {trend }}(x, t)\right)$; an annual 

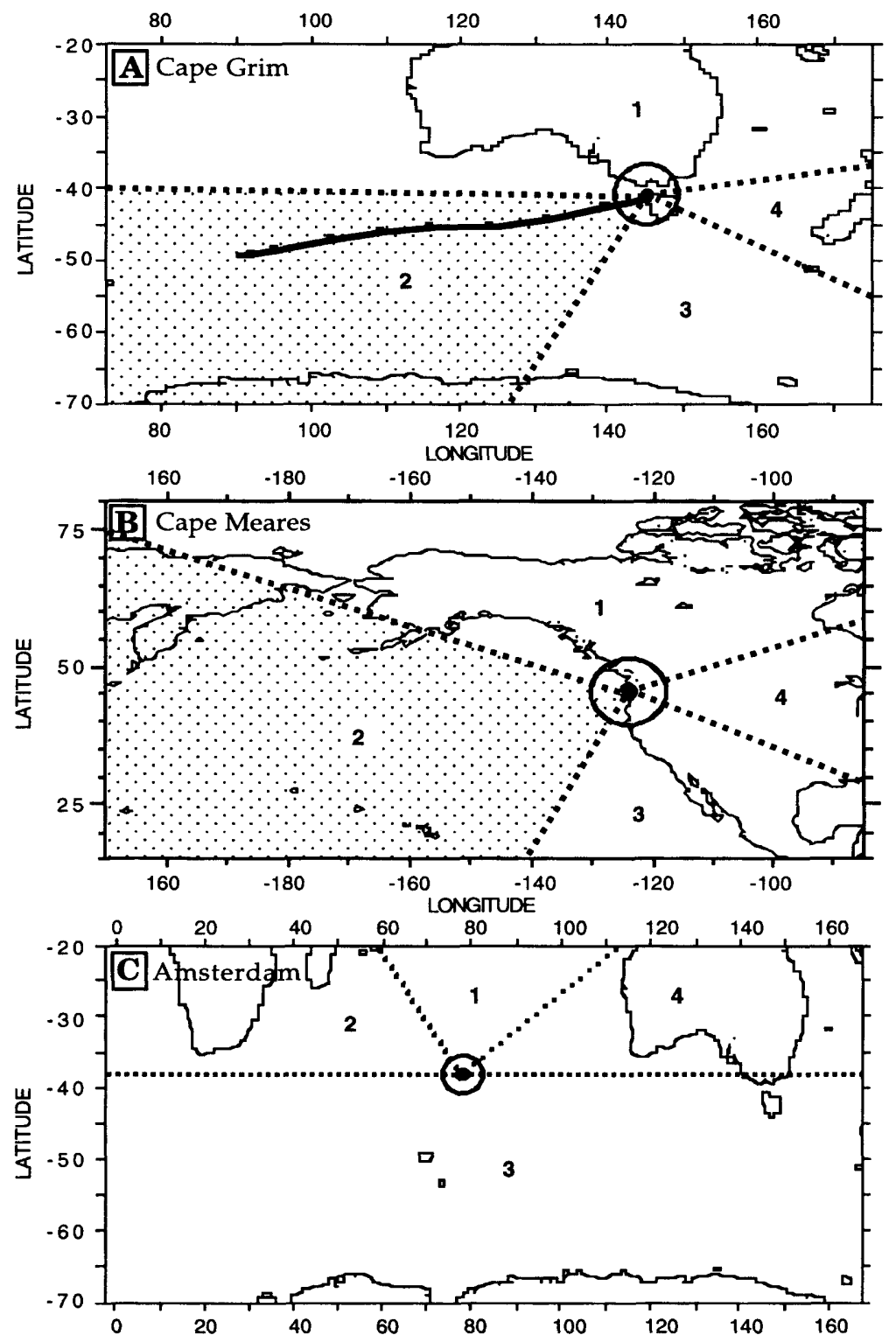

Fig. 1. Definition of the sectors used to sort out the 5-days backtrajectories at (A) Cape Grim, (B) Cape Meares, and (C) Amsterdam Island. For Cape Grim and Cape Meares, the baseline sectors correspond to the sector number 2 (southwest sector). An example of a selected backtrajectory, calculated for Cape Grim on 1990 August 20 at 12 h, is also displayed.

mean $\left(C_{\text {mean }}(x)\right)$; and a seasonal variation $\left(C_{\text {seas }}(x, t)\right)$ expressed as the sum of the 1 st 4 harmonics of a base period of 1 year:

$$
\begin{aligned}
C(x, t)= & C_{\text {trend }}(x, t)+C_{\text {mean }}(x) \\
& +C_{\text {seas }}(x, t)+C_{\text {residu }}(x, t),
\end{aligned}
$$

$$
\begin{aligned}
& C_{\text {trend }}(x, t)=C_{0}(x)+a_{0}(x) \cdot t \\
& C_{\text {seas }}(x, t)=\sum_{k=1}^{4}\left[a_{k}(x) \sin (2 k \pi) t+b_{k}(x) \cos (2 k \pi) t\right] .
\end{aligned}
$$

The residuals $\left(C_{\text {residu }}(x, t)\right)$ reflect the synoptic scale 
Table 1. Criteria used at Cape Grim and Amsterdam Island to select the baseline conditions (WD=Wind direction, $W V=$ Wind velocity)

\begin{tabular}{|c|c|c|c|}
\hline Station & Wind direction & Wind speed & $\mathrm{CO}_{2}$ consistency \\
\hline Cape Grim & $190^{\circ}<\mathrm{WD}<280^{\circ}$ & no criteria & $\begin{array}{l}\text { Variation }< \pm 0.3 \text { ppmv during a } 5-\mathrm{h} \\
\text { period }\end{array}$ \\
\hline Cape Meares & $\begin{array}{l}\text { air masses should } \\
\text { come from ocean } \\
\text { during the sampling }\end{array}$ & no criteria & $\begin{array}{l}\text { - difference between } 2 \text { flasks }<0.5 \mathrm{ppmv} \\
\text { - } 3 \text { sigma deviation from a fitted curve }\end{array}$ \\
\hline Amsterdam Island & $\begin{array}{l}300^{\circ}<\mathrm{WD}<50^{\circ} \\
260^{\circ}<\mathrm{WD}<300^{\circ}\end{array}$ & $\begin{array}{l}W V \geqslant 5 \mathrm{~m} \mathrm{~s}^{-1} \\
W V>8 \mathrm{~m} \mathrm{~s}^{-1}\end{array}$ & at least 4 consecutive baseline hours \\
\hline
\end{tabular}

variations, on time scales from days to a few weeks. The same procedure is applied to the concentrations observed in 1990, and the results of simulations.

The goal of this work is to use the previously described model and fluxes, to study the influence of selecting the baseline periods in the simulated time series. However, to test whether such a procedure improves the agreement between model and data, we need to use realistic surface fluxes and transport model. In order to demonstrate this, we have plotted the seasonal cycles for two stations (South Pole and Mauna Loa) whose simulated data do not need to be selected, since they are not subject to a local component. The observed and simulated seasonal cycles for the year 1990, are shown on Fig. 2. Both the amplitude and the phase of the signals are well simulated, which gives us some confidence in the transport model and the fluxes for both hemispheres.

\section{Selection of the simulated tracer concentrations}

\subsection{Description of four types of model baseline selection}

The problem of comparing baseline measurements with the simulated time series without any selection, was pointed out by Heimann et al. (1989a), and Enting and Trudinger (1990). However, these two studies were carried out with coarse resolution models. Consequently, the high frequency variations due to the regional contribution were very smooth. For example, Enting and Trudinger (1990) analyzed the amplitude of synoptic scale variations at Cape Grim. Their results did not permit to evaluate the interest of a baseline selection in transport models, mainly because the simulated short term variability was underestimated. Thus, the authors did not obtain any significant difference between the selected and the non-selected simulated concentrations. In their study, Enting and Trudinger (1990) selected the baseline periods according to the values of the wind direction simulated by the model at the Cape Grim location. We use a similar method for Cape Grim, Cape Meares and Amsterdam, based on the wind speed and wind direction from ECMWF at the station locations. These meteorological data allow us to define baseline sectors, for what will be called hereafter the "local-selection".

As an alternative mean of defining the baseline periods in the transport models, we have also selected the same periods as for the baseline measurements. This method is questionable because it assumes that synoptic transport is well resolved by the models, and then it does not account for differences between real atmospheric transport and simulated transport. However, we have applied this selection, called hereafter the "synchro-selection", because we use a meteorological transport model which is "a-priori" able to simulate synoptic scale variations synchronized with real weather. Such a synchro-selection would be irrelevant if we used a climatological model (i.e. not based on observed meteorological conditions). With such a model there is no reason for the observed and simulated baseline periods to be synchronized.

The two previous methods are attractive due to their simplicity, yet they do not use any information about the history of the air masses before they reach the monitoring location. Since this information is available for the simulated concentrations, we have defined two more sophisticated 

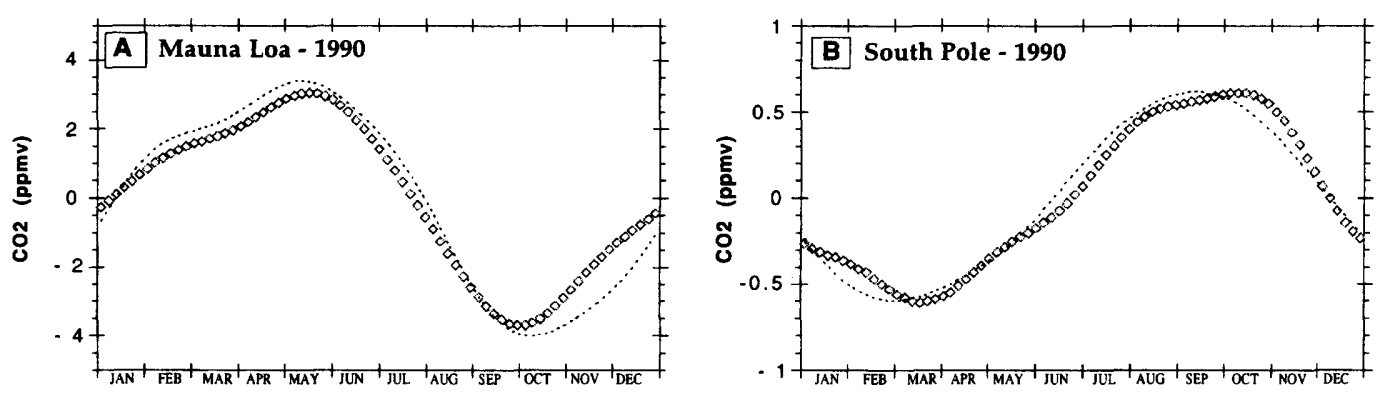

Fig. 2. Seasonal cycles of atmospheric $\mathrm{CO}_{2}$ at Mauna Loa (A) and South Pole (B) in 1990. The baseline measurements $(\diamond)$ are compared to the simulated cycle without any selection (dotted line).

methods. These two methods are based respectively on the backtrajectories, and on the simulated concentrations of radon-222. The former, called "retro-selection", selects only specific air masses according to the 5-days backtrajectories calculated with the TM $2 z$ (Ramonet et al., 1996). The backtrajectories are rarely used to select the observed concentrations (Enting, 1989). Yet, they are more suitable for the simulations since they are based on the wind fields also used by the transport model. We have used different methodologies for coastal stations, and for remote islands like Amsterdam. For the coastal stations, we consider that all the air masses recently influenced by land should be rejected. This is performed by first defining the marine sectors, and second rejecting all the periods during which the backtrajectory is not totally included within this sector. The marine sectors defined for Cape Grim and Cape Meares are shown on Fig. 1. In a remote station like Amsterdam Island, the simulated influence of the island is null since it is too small to be resolved by the model. Consequently, all the simulated events can be classified as baseline ones. However, a high percentage of observed hourly concentrations are rejected at this station due to the influence of the island and the station activities (Gaudry et al., 1983). This severe selection leads to favor some specific meteorological situations, and then some air mass origins. By oversampling the air masses coming from a particular source or sink region, the monthly and annual means can be different to the data we would obtained if all the meteorological situations were taken into account. To reproduce a similar sampling in the transport model we have defined four geographical sectors (Fig. 1) and we have applied the following method. First, we have calculated for the whole year of 1990 the backtrajectories corresponding to the date and time of each baseline measurement. From these we have deduced the monthly percentages of backtrajectories occurring in each of the four sectors. These percentages are different from those obtained by using all the backtrajectories, including baseline and non baseline periods. Second, the hourly simulated concentrations have been split into four categories according to the origin of the synchronous backtrajectories. This gave us four sets of simulated monthly means, typical of each of the four sectors. Finally, a composite of these four sets of $\mathrm{CO}_{2}$ monthly means, weighted by the percentages deduced from the backtrajectories at the time of the baseline observations, has been calculated. This method allows us to approximate the observational sampling in the simulated time series at the seasonal scale.

The fourth selection method takes also into account the synoptic scale transport. It is based on the radon-222 simulation which allows to classify the air masses as marine or continental ones. radon- 222 is a rare gas emitted from the continents, and decays with a half-life of 3.8 days. Under marine conditions the air masses are characterized by low radon-222 concentrations. To eliminate the influence of the close continents we have chosen a threshold concentration of radon-222, below which the situation is considered as baseline. The threshold was set to $500 \mathrm{mBq}$ $\mathrm{m}^{-3}$, since the higher concentrations are representative of a recent contact with land (Lambert et al., 1982). The radon-222 simulation was performed with a uniform continental source of 
1 atom $\mathrm{cm}^{-2} \mathrm{~s}^{-1}$ (Lambert et al., 1982; Liu et al., 1984).

\subsection{Discussion on model baseline selected time series}

The simulated hourly concentrations are shown on Fig. 3 to Fig. 5, respectively for the stations of Cape Grim, Cape Meares and Amsterdam. On these plots the simulated annual means have been subtracted from the hourly values. The selected data, according to the four methods described in the previous section, are figured by larger dots. It should be noted that the vertical scales are not the same for the three stations, since the synoptic scale variations simulated by the $\mathrm{TM} 2 z$ are much more important at Cape Grim than at Amsterdam, and the seasonal cycle is much higher at Cape Meares. Furthermore, there is no plot of the retroselection at Amsterdam Island, since we used for this remote island a different method which does not allow to select individual events, as explained in the previous section. Table 2 summarizes, for each station and each method, the number of selected data, and the annual standard deviations of the hourly residuals $C_{\text {residu }}(x, t)$. Residuals are the remaining variations after subtracting a linear trend, the annual mean, and the seasonal cycle calculated as the sum of the first four harmonics (eq.(1)) The four selection methods do not retain the same periods, which means that they are not equally efficient to reject the non-baseline events. However, the local-selection is highly correlated to the synchro-selection at Cape Grim and Amsterdam Island $(r=0.88$ at Cape Grim, when comparing the number of selected data during 5 days periods). This is due to the correlation between the wind values analyzed at ECMWF and those measured at the stations.

The concentrations simulated at Cape Grim (Fig. 3) show strong positive events in autumn (April to July), and negative ones in spring (September to November). The amplitude of these synoptic scale variations is typically about $5 \mathrm{ppmv}$. The duration and the intensity of these events indicate that they are due to an intense regional source or sink. Furthermore, the contribution of oceanic, industrial and biospheric components, not shown on the figure, clearly indicates a biospheric origin. So, the seasonality of these synoptic peaks can be explained by an uptake of atmo- spheric $\mathrm{CO}_{2}$ in spring due to photosynthesis, and a built-up in autumn due to soil respiration over Tasmania and Australia. Such kind of strong synoptic peaks are rejected from the observations by using wind direction and consistency criterion (Table 1; Beardsmore and Pearman, 1987). Hence, a good way to estimate the efficiency of the four baseline selections described previously, is to compare how well they succeed to reject these synoptic events. The local and synchro-selections, shown on Fig. 3, do not filter out the high frequency variations (positive ones in autumn, negatives ones in spring) as well as the radon-222 and retroselections. This is confirmed by the calculations of the annual standard deviations of the residuals (Table 2). The results of simulations with the TM $2 z$ show a standard deviation which decreases from $1.06 \mathrm{ppmv}$ without selection, to 0.65 and $0.48 \mathrm{ppmv}$ respectively with the local and synchroselection. Such a variability remains overestimated in comparison with the baseline measurements (s.d. $=0.24 \mathrm{ppmv}$ ). A better agreement is found when we use the retro (s.d. $=0.35$ ppmv) and the radon-selection ( $\mathrm{s} . \mathrm{d} .=0.38 \mathrm{ppmv}$ ).

At Cape Meares, the synchro-selection is based on very few data, since there are no continuous measurements. 66 pairs of flasks were considered as representative of the baseline conditions in 1990. As seen previously the baseline selection of the measurements is not done according to the local wind speed and direction, since these data are not available. For the local-selection, we have chosen the following criteria: wind direction between $200^{\circ}$ and $340^{\circ}$; and wind speed greater than $5 \mathrm{~m} \mathrm{~s}^{-1}$. The results display features like that of the results obtained at Cape Grim. For instance, the synchro and local-selections are not efficient enough to reject the sharp synoptic variations, i.e. the positive events which occur in winter and the negative events in summer (Fig. 4). The radon and retro-selection are much more efficient to reject such events. Consequently the standard deviations of the residuals inferred from these selections (s.d. $=1.1 \mathrm{ppmv}$ ) is lower that the synchro (s.d. = $3.6 \mathrm{ppmv}$ ) and local (s.d. $=2.0 \mathrm{ppmv}$ ) selections. In comparison, the annual standard deviation of the residuals calculated from the baseline measurements in 1990 is 1.4 ppmv (Table 2). This is slightly greater than the simulated values even after the baseline selections. A plausible explanation for this difference lies in the fact that the criteria used 

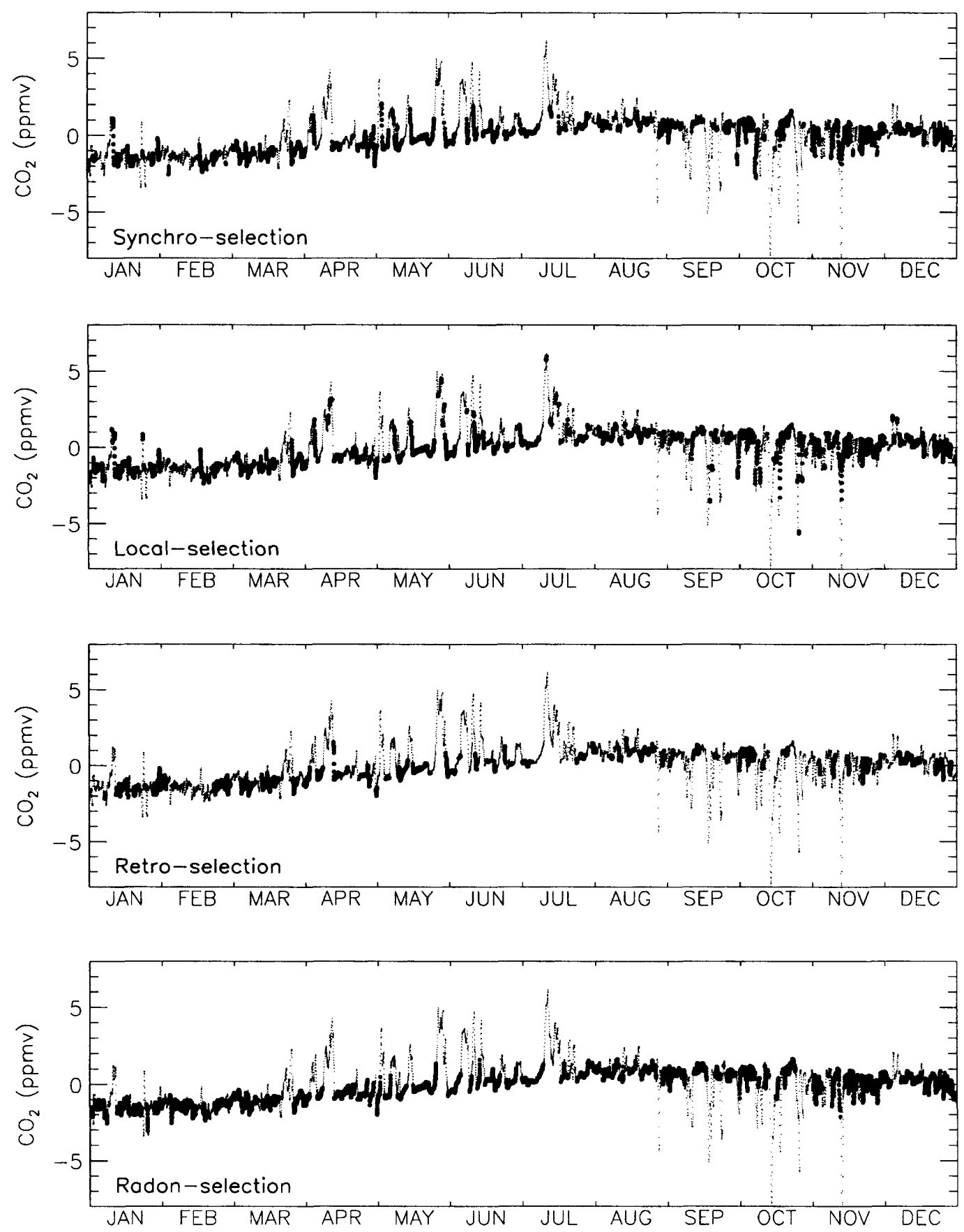

Fig. 3. Hourly concentrations of $\mathrm{CO}_{2}$ simulated in 1990 at Cape Grim with the TM2z. The simulated annual mean is subtracted to each value. The baseline data (large dots) are selected according to (A) the synchro-selection, (B) the local-selection, (C) the retro-selection, and (D) the radon-selection (radon-222<500 $\mathrm{mBq} \mathrm{m}^{-3}$ ). 

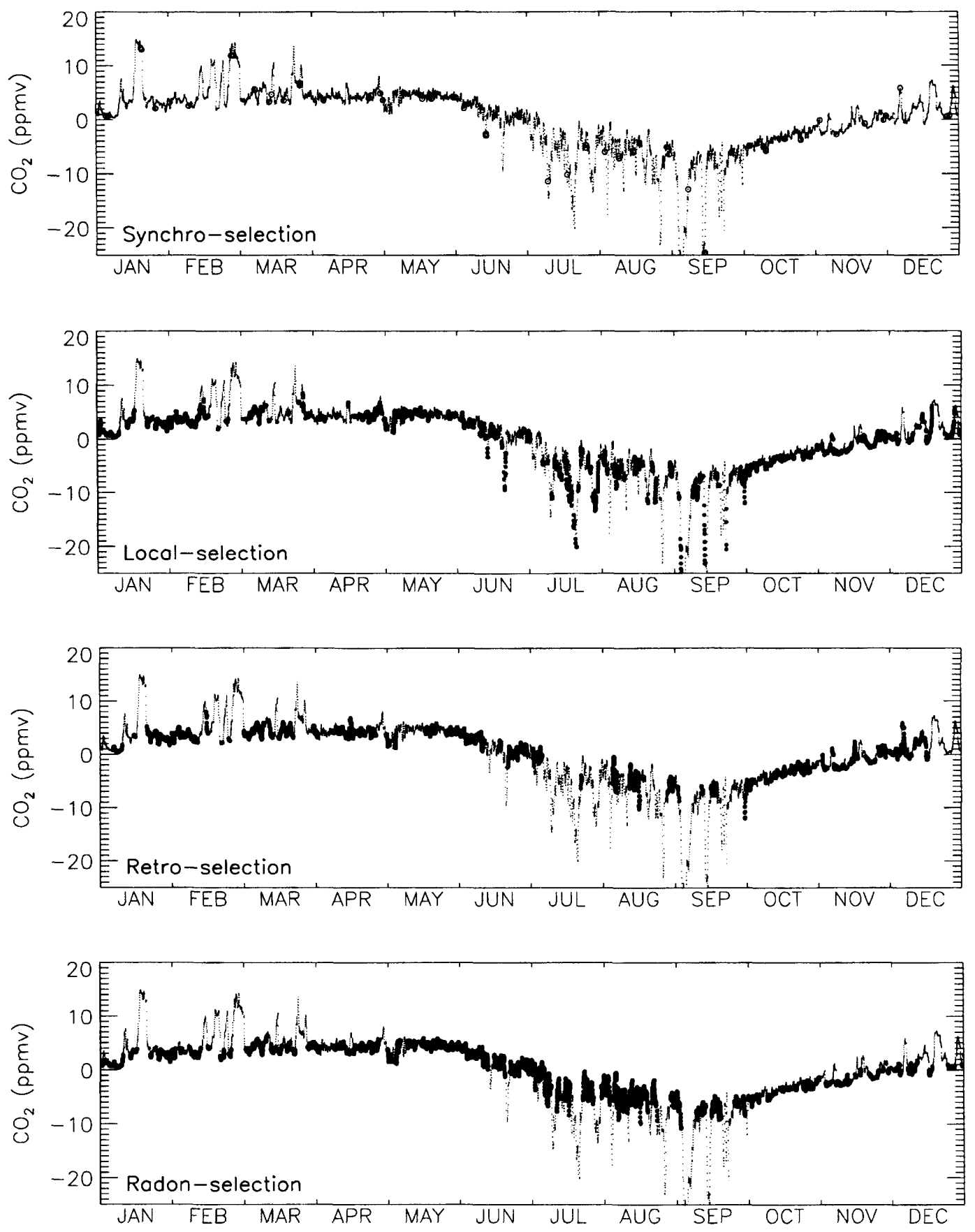

Fig. 4. Hourly concentrations of $\mathrm{CO}_{2}$ simulated in 1990 at Cape Meares with the TM2z. The simulated annual mean is subtracted to each value. The baseline data (large dots) are selected according to (A) the synchro-selection, (B) the local-selection, (C) the retro-selection, and (D) the radon-selection (radon- $222<500 \mathrm{mBq} \mathrm{m}^{-3}$ ). 

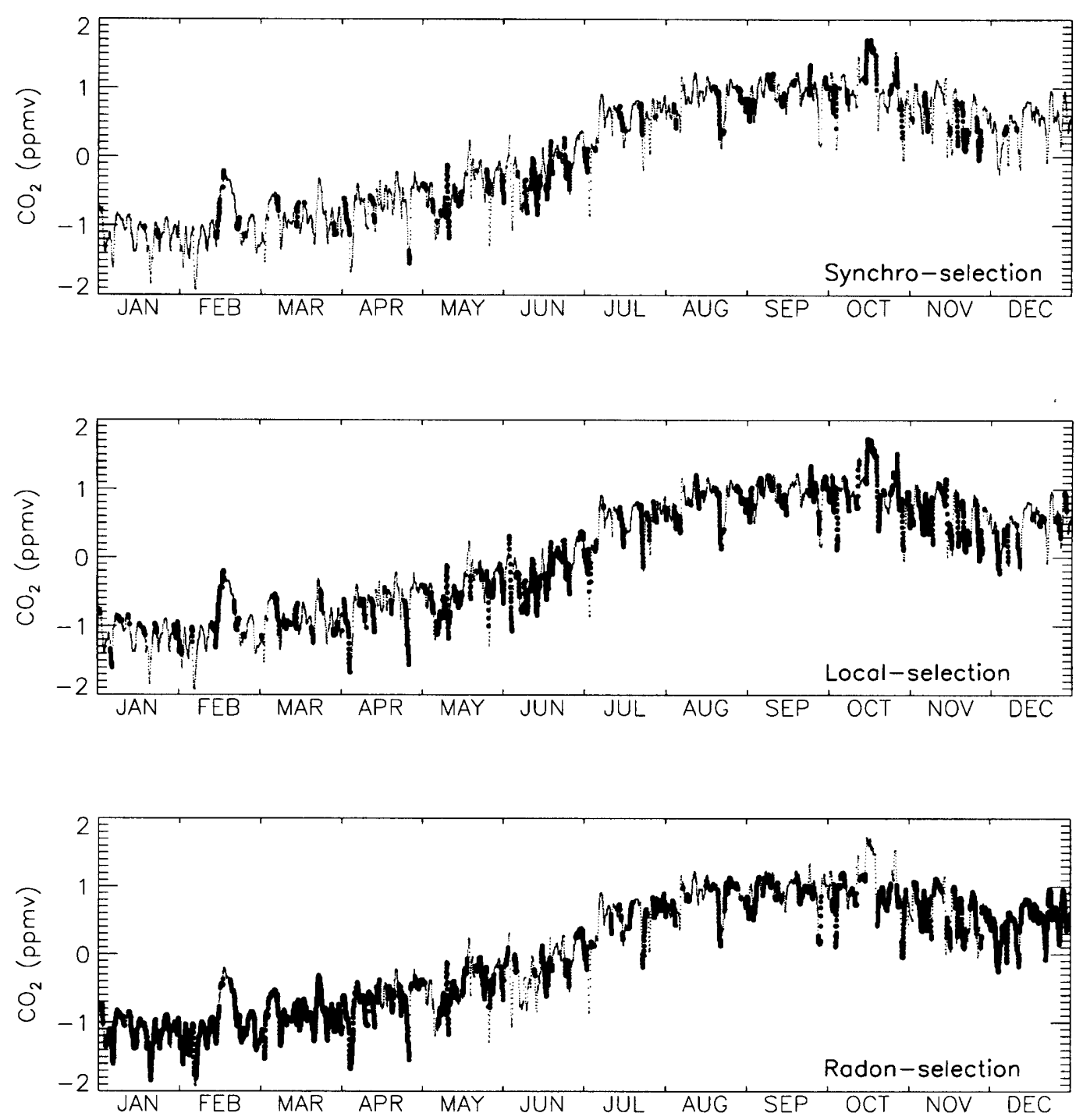

Fig. 5. Hourly concentrations of $\mathrm{CO}_{2}$ simulated in 1990 at Amsterdam Island with the TM2z. The simulated annual mean is subtracted to each value. The baseline data (large dots) are selected according to (A) the synchro-selection, (B) the local-selection, (C) the radon-selection (radon- $222<40 \mathrm{mBq} \mathrm{m}^{-3}$ ).

to select the observations (Table 1) may not exclude entirely the non baseline conditions. The retro or radon-selection may be more efficient to reject the regional component from the simulated time series. This is especially true for the flask sites where it is more difficult to identify the baseline data.

At Amsterdam Island the baseline selection of the observations is less critical, since it induces changes on the observed monthly means lower than 0.2 ppmv. The model does not resolve the Amsterdam Island, and consequently it does not simulate strong peaks as it does at Cape Grim and Cape Meares (Fig. 5). As a result, there is no major difference in the annual standard deviation of the residuals obtained with and without selection (s.d. ranges from 0.24 to $0.27 \mathrm{ppmv}$ ), though the number of selected data are very scattered 
Table 2. Results of the baseline selections for observed and simulated time series in 1990

\begin{tabular}{lllclll}
\hline & \multicolumn{2}{c}{ Cape Grim } & \multicolumn{2}{c}{ Cape Meared } & \multicolumn{2}{c}{ Amsterdam } \\
& $N(\mathrm{~h})$ & $\mathrm{SD}(\mathrm{ppmv})$ & $N(\mathrm{~h})$ & $\mathrm{SD}(\mathrm{ppmv})$ & $N(\mathrm{~h})$ & SD $(\mathrm{ppmv})$ \\
\hline measurements 1990 & 8200 & 1.89 & 88 & 2.74 & 8255 & 0.63 \\
baseline measurements & 3470 & 0.24 & $66^{\#}$ & 1.40 & 1277 & 0.28 \\
TM2z: no selection & 8760 & 1.06 & 8760 & 3.17 & 8760 & 0.27 \\
TM2z: synchro-selection & 3470 & 0.48 & 66 & 3.58 & 1277 & 0.24 \\
TM2z: local-selection & 3782 & 0.65 & 3305 & 1.98 & 3190 & 0.27 \\
TM2z: retro-selection & 2664 & 0.35 & 3696 & 1.09 & - & - \\
TM2z: radon-selection * & 5434 & 0.38 & 4889 & 1.10 & 5645 & 0.25 \\
\hline
\end{tabular}

For each station the first column corresponds to the number of selected hours, and the second one corresponds to the annual standard deviations of residuals (detrended and deseasonalised data).

\# Number of selected flask pairs.

* The radon-222 threshold is equal to $500 \mathrm{mBq} \mathrm{m}{ }^{-3}$ for Cape Grim and Cape Meares, and $40 \mathrm{mBq} \mathrm{m}^{-3}$ for Amsterdam Island.

(from $14.6 \%$ to $100 \%$ ). The annual variability of the simulated residuals is very close to the observed baseline variability which is $0.28 \mathrm{ppmv}$ in 1990 (Table 2). It is worth noting that, according to the transport model, the major contribution to the residuals (i.e. to the synoptic scale variations) comes from the oceanic fluxes. The annual standard deviation of the residuals is $0.27 \mathrm{ppmv}$ for the oceanic component, $0.14 \mathrm{ppmv}$ for the industrial component, and $0.10 \mathrm{ppmv}$ for the biospheric component. The radon-selection at Amsterdam Island was performed with a threshold $\left(40 \mathrm{mBq} \mathrm{m}^{-3}\right)$ lower that the threshold used for Cape Grim and Cape Meares. This value enables us to remove the periods of high radon- 222 concentration at this station. Indeed the radon-222 concentration at Amsterdam is generally between 10 and $50 \mathrm{mBq} \mathrm{m}^{-3}$ (Polian et al., 1986). Using a $40 \mathrm{mBq} \mathrm{m}^{-3}$ threshold, $35.6 \%$ of the simulated values are rejected, with highest percentages in wintertime. During this period, radon-222 concentrations are characterized by sharp increases, called radonic storms, which are due to rapid advection of air masses from South Africa or South America (Polian et al., 1986; Heimann et al., 1990). The baseline criteria used to select the $\mathrm{CO}_{2}$ measurements at this observatory do not distinguish such continental events. So this model selection do not truly compare to the observations. However it is interesting to note that the radon-222 criterion can be used to select the continental events originating from South Africa
(Gaudry et al., 1990). Such a regional scale event will be detailed in the subsection 3.4.

\subsection{Influence of model baseline selections on seasonal cycles and annual means}

As seen previously the characteristics of the non-baseline events (frequency, amplitude, sign) display strong seasonal variations both at Cape Grim and Cape Meares. As a result, we can expect the selections being able to modify the seasonal cycles at these stations. In the present section we detail how the annual cycles are changed due to the selections, with a view to estimating if such corrections can explain the discrepancies found in the model/data comparisons.

At Cape Grim the amplitude of the simulated annual cycle, without selection, is overestimated by 0.9 ppmv in comparison to the baseline measurements. Furthermore, the simulated maximum concentration occurs one month and half too early (Fig. 6). All the selections improve greatly the comparison model/data since they reduce the simulated amplitude by about $0.6 \mathrm{ppmv}$, and delay the wintertime peak between 1 and 2 months. Hence, at seasonal scale even a far from perfect selection, such as the local-selection, improves the comparison between observations and simulations. However the retro and radon-selection bring the simulated cycle to a better agreement with baseline observations. These two model selections 


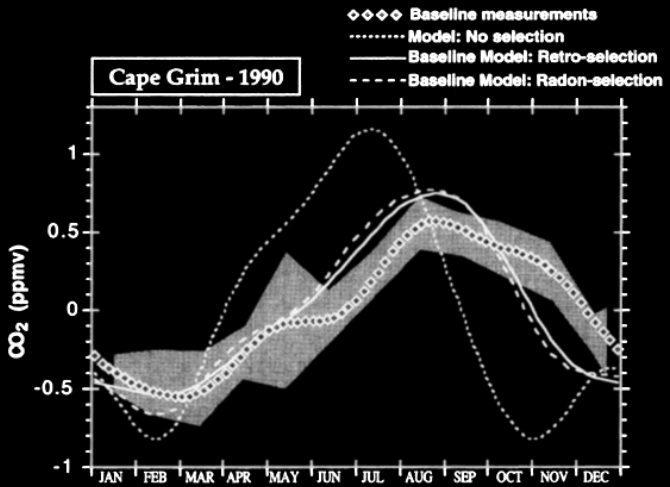

Fig. 6. Seasonal cycle of atmospheric $\mathrm{CO}_{2}$ at Cape Grim in 1990. The baseline measurements ( ) are selected according to the criteria defined by Beardsmore and Pearman, 1987. The shaded area shows the standard deviation ( \pm one s.d.) of the selected data from the smoothed curve, calculated on a monthly basis. The simulated cycle is displayed before (dotted line), and after the baseline model selection according to the radonselection (dashed line), and the retro-selection (solid line).

are displayed on Fig. 6. The seasonal cycle inferred from the radon-selection does not change a lot if we decrease the threshold selection to $100 \mathrm{mBq}$ $\mathrm{m}^{-3}$ in order to have a more restrictive selection. As is made clear by Fig. 6, the lack of selection in the model makes necessary to explain the discrepancy in model/data comparison by looking at the simulation of either atmospheric transport or surface fluxes, which is no more the case after the baseline selection. According to our model, the major contribution to the seasonal cycle at Cape Grim is due to the terrestrial biosphere.

At Cape Meares the annual cycle of atmospheric $\mathrm{CO}_{2}$ is 10 times stronger and of opposite phase, in comparison to Cape Grim (Figs.6, 7). This is consistent with estimates of the annual cycle of terrestrial biosphere, which is the major contribution to the atmospheric $\mathrm{CO}_{2}$ seasonality (Fung et al., 1987, Heimann et al., 1989a; Manning, 1993). The annual amplitude simulated by the TM $2 z$ is overestimated by about $70 \%$ (Fig. 7). An overestimation of the peak to peak amplitude at this station was also emphasized by Erickson et al. (1996). Our results point out that a large part of this discrepancy can be explained by the inconsistency of model/data comparison when the simulated concentrations are not selected. Thanks to the radon and retro-selections the discrepancy

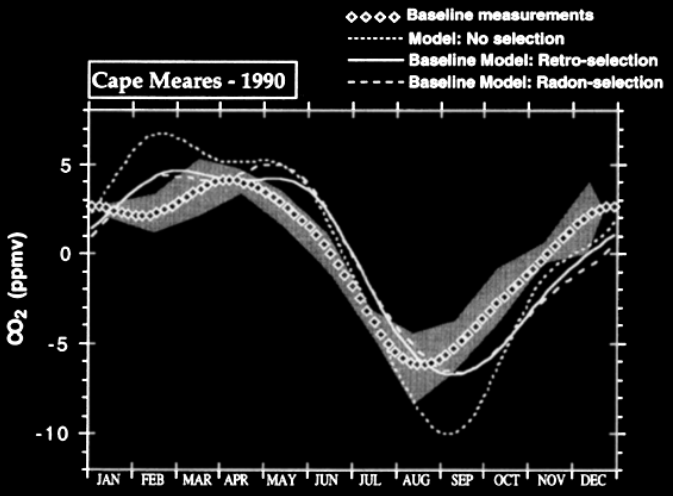

Fig. 7. Seasonal cycle of atmospheric $\mathrm{CO}_{2}$ at Cape Meares in 1990. The baseline measurements (1) are selected according to the criteria defined by Conway et al., 1994. The shaded area shows the standard deviation ( \pm one s.d.) of the selected data from the smoothed curve, calculated on a monthly basis. The simulated is displayed before (dotted line), and after the baseline selection according to the radon-selection (dashed line), and the retro-selection (solid line) .

between observed and simulated amplitudes peak to peak is reduced to only $18 \%$ (Fig. 7). On the other hand there is no improvement of the phase when we apply the selection to the simulated values. The simulated phase is delayed by about 1 month compared to the measurements, involving some problems with the simulation of atmospheric transport or the biospheric fluxes. Particularly the soil respiration is crudely treated since its temporal variation is only driven by the surface temperature (Heimann et al., 1989b).

At Amsterdam Island the terrestrial biosphere is also the main contributor to the seasonal cycle of atmospheric $\mathrm{CO}_{2}$, though the island is far from the continents. In fact, according to our model, half of the terrestrial biospheric contribution comes from the biosphere north of $30^{\circ} \mathrm{N}$, and the other half comes from the biosphere south of $30^{\circ} \mathrm{S}$ (Ramonet, 1994). However, the oceanic contribution is more important than at Cape Grim which lays at the same latitude. This contribution has a semi-annual period with 2 minimums in $\mathrm{CO}_{2}$ concentrations occurring in May/June and November/December (Ramonet, 1994; Metzl et al., 1995). The second harmonic is also observed in the measurements, and it explains partly the specificity of the seasonal cycle of atmospheric $\mathrm{CO}_{2}$ at Amsterdam. Nevertheless, the transport 
model overestimates the amplitude of the seasonal cycle observed in 1990 ( +0.4 ppmv peak to peak), and the model selections cannot account for this discrepancy (Fig. 8). The radon-selection presented on Fig. 5 (threshold $=40 \mathrm{mBq} \mathrm{m}^{-3}$ ) have very low percentages of rejected values, and do not change the simulated seasonal cycle. On the other hand, the synchro-selection is more influenced by synoptic scale events, and so the selection can modify the monthly means by about $0.3 \mathrm{ppmv}$ (Fig. 8), which is the order of magnitude of the synoptic scale variations (Table 2). The selection based on the backtrajectories, as explained above, give similar results than the synchro-selection. We see an improvement of the seasonal cycle at the beginning of the year (February), corresponding to the fact that baseline conditions in summertime select preferentially North backtrajectories (sector 1 on Fig. 1).

An important feature for the global carbon cycle is the sensitivity of the $\mathrm{CO}_{2}$ annual means to the model selections. Table 3 resumes the differences between the simulated annual mean with and without selection. Two kinds of calculations were performed by using either the hourly simulated concentrations, or the monthly averages. The reason why the annual means calculated from hourly or monthly concentrations can differ each other, is that the selection can reject more values

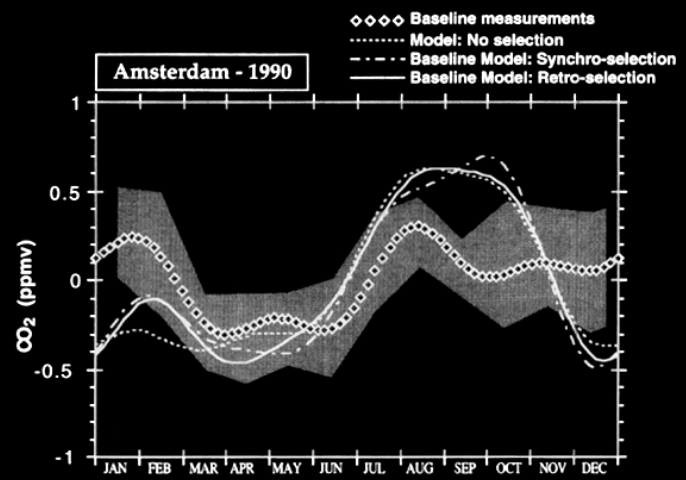

Fig. 8. Seasonal cycle of atmospheric $\mathrm{CO}_{2}$ at Amsterdam Island in 1990. The baseline measurements (客) are selected according to the criteria defined by Gaudry et al., 1987. The shaded area shows the standard deviation ( \pm one s.d.) of the selected data from the smoothed curve, calculated on a monthly basis. The simulated is displayed before (dotted line), and after the baseline selection according to the synchro-selection (dotted-dashed line), and retro-selection (solid line). at a given season. In such a case, using the selected hourly concentrations would gives a less important weight to the season for which more data are rejected, thereby biasing the calculation of annual mean. For instance the annual means calculated at Cape Grim, Cape Meares and Amsterdam differ from $0.1,1.0$ and 0.2 ppmv respectively, simply by using either monthly or hourly concentrations (Table 3). Consequently the selection of the simulated values constrains us to derive the annual means from the monthly means. Then, the baseline selection shift the simulated annual means of about $-0.17 \pm 0.02 \mathrm{ppmv}$ at Cape Grim, and $-0.02 \pm 0.01 \mathrm{ppmv}$ at Amsterdam Island (Table 3B). At Cape Meares the shift of the annual means, induced by the selection, are much more scattered since they range from $-0.97 \mathrm{ppmv}$ (synchro-selection) to $+0.41 \mathrm{ppmv}$ (radonselection), which means that the choice of the selection method is not harmless. There is a $0.4 \mathrm{ppmv}$ difference in the annual means deduced from the radon and retro-selections, although the seasonal cycles were very similar. Much of the explanation for the difference rests with the poor temporal resolution of the backtrajectories which are calculated only once per $12 \mathrm{~h}$. When a backtrajectory satisfies the baseline condition we select the concentrations over a $12 \mathrm{~h}$ period centered on the date and time of the backtrajectory ( 0 or $12 \mathrm{GMT}$ ). So there is a possibility to select some non-baseline data which occurred between 0 and 12 GMT. Effectively the bases of strong synoptic peaks are sometime selected. This occurs mainly in wintertime because there are very few selected periods during summertime (Fig. 4). Finally, it is worth noting that model studies using observed North/South gradient of atmospheric $\mathrm{CO}_{2}$ have to account carefully for baseline selection in theirs own simulated values.

\subsection{Toward a new use of models: the regional scale}

In the previous sections we discussed about the differentiation between the simulated baseline and non-baseline $\mathrm{CO}_{2}$ variations. Our results demonstrate the interest for such a selection in 3-D transport models, in order to be more consistent with the baseline observations. In the present section, we focus on the periods which are classified as non-baseline, and then rejected. The question is to know how helpful these data could be 
Table 3. Annual means (ppmv) observed in 1990, and simulated by the TM2z according to the 4 baseline selections, referenced to the annual mean obtained without selection

\begin{tabular}{|c|c|c|c|}
\hline & Cape Grim & Cape Meares & Amsterdam \\
\hline \multicolumn{4}{|c|}{ (A) From hourly data } \\
\hline measurements & -0.58 & -1.06 & +0.06 \\
\hline synchro-selection & -0.13 & -0.48 & +0.14 \\
\hline local-selection & -0.10 & +0.31 & +0.13 \\
\hline retro-selection & -0.25 & +1.26 & 0.00 \\
\hline radon-selection * & -0.16 & +0.32 & -0.17 \\
\hline \multicolumn{4}{|c|}{ (B) From monthly averages } \\
\hline measurements & -0.65 & -1.00 & -0.03 \\
\hline synchro-selection & -0.19 & -0.97 & -0.03 \\
\hline local-selection & -0.14 & -0.66 & -0.03 \\
\hline retro-selection & -0.14 & +0.41 & -0.01 \\
\hline radon-selection * & -0.14 & +0.01 & -0.01 \\
\hline
\end{tabular}

Positive values mean that the baseline selection increases the annual mean. (A) Annual means are calculated from hourly concentrations. (B) Annual means are calculated from monthly averages.

* The Radon-222 threshold is equal to $500 \mathrm{mBq} \mathrm{m}{ }^{-3}$ for Cape Grim and Cape Meares, and $40 \mathrm{mBq}^{-3}$ for Amsterdam Island.

in the study of the regional sources and sinks of $\mathrm{CO}_{2}$. Due to the refining of transport parameterizations, as well as horizontal and vertical resolutions, the models are expected to be more and more qualified to interpret the regional scale variations. As a preliminary study, we detail in this section the simulation by the TM $2 z$ of some synoptic events which occurred at Cape Grim and Amsterdam Island in 1990.

The Fig. 9 displays a comparison of $\mathrm{CO}_{2}$ simulations and observations at Cape Grim in March/April 1990. At the synoptic scale, we can distinguish between three situations: (1) low variations which generally correspond to the baseline periods; (2) high variations occurring both in measurements and simulation; (3) very strong diurnal variations observed only in the measurements. For instance, the model fails to simulate the strong diurnal cycles observed at the beginning of March, and around the 20 April. On the contrary the synoptic events simulated around the 25 March and 13 April are well synchronized with the observations, though the model does not resolve the diurnal cycle. However these two events are rejected as non-baseline. The backtrajectory calculated on 13 April indicates an origin from the North. So this synoptic event is related to the $\mathrm{CO}_{2}$ fluxes exchanged over southeast of Australia. On 20 April we deal with an air mass coming from the East which has flown over
Tasmania. So the second case seems to be characterized by a more local situation. To confirm this difference, we have performed a simulation with a source of radon-222 activated only over Tasmania. In Fig. 9, measurements are displayed with either continuous or dashed line. The latter corresponds to periods for which the TM $2 z$ simulates high concentrations of radon-222 emitted from Tasmania. The model has more difficulties to reproduce the $\mathrm{CO}_{2}$ variations during these periods. For such cases, a major deficiency of the model concerns its coarse vertical resolution in the low troposphere, which makes impossible the representation of the dynamic of the planetary boundary layer over continents (Monfray et al., 1996). The transport from Australia to Tasmania is resolved by the model, but not the nocturnal built-up of $\mathrm{CO}_{2}$ which is linked to the dynamic of the PBL and the sea/land breeze. At the present time all the non-baseline situations are equally discarded both in observed and simulated time series. It would be interesting to make a distinction between local events not resolved by the transport model, and regional scale events which are pretty well simulated. These $\mathrm{CO}_{2}$ variations could help us to constraint the regional distribution of sources and sinks of carbon. They can also be of interest as a test of the parameterization of the PBL, though high frequency data of the vertical distribution of 


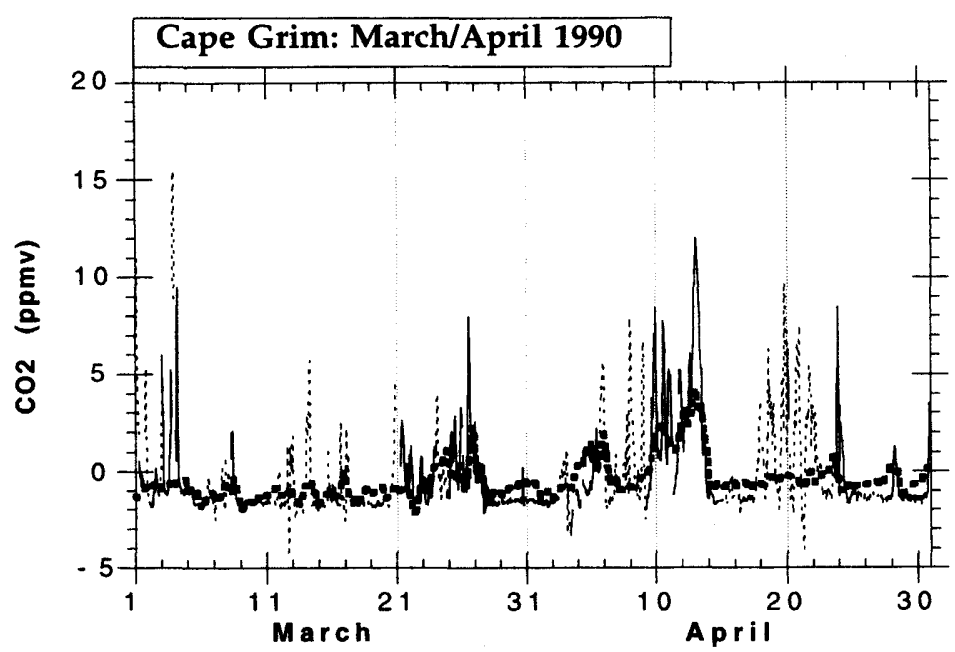

Fig. 9. Measurements (thin lines) and simulation (bold dotted line) of $\mathrm{CO}_{2}$ concentrations at Cape Grim in March/April 1990. The measurements are represented in thin dotted line when the TM $2 z$ calculates high radon-222 concentrations originating from Tasmania.

$\mathrm{CO}_{2}$, and other short life tracers, will be needed to improve this parameterization.

In the subsection 3.2, we discussed the radonic storms which occur at Amsterdam Island, especially during wintertime. Gaudry et al.(1990) used these synoptic events to characterize the biospheric fluxes over South Africa. Some uncertainties, about the transit times and the spatial distribution of $\mathrm{CO}_{2}$ fluxes, could be reduced with a transport model, provided that it is able to simulate synoptic scale variations. Fig. 10 displays an example of a radonic storm observed at Amsterdam Island between 16-20 October, 1990 (open square), which is also simulated by the model TM $2 z$ (dashed line). Two kinds of $\mathrm{CO}_{2}$ measurements are displayed, together with their hourly standard deviation. Open circles correspond to the baseline measurements as defined by Gaudry et al. (1987) (subsection 2.2). Since very few data are selected as baseline, it is difficult to make clear where are the positive and negative synoptic scale variations. Then we have expanded the baseline periods by using the following criteria: hourly standard deviation less or equal than $0.2 \mathrm{ppmv}$; and the hourly mean concentrations which differ from the 6 hours average (centered on the hour of interest) by no more than 0.15 ppmv. These data are shown by their hourly standard deviation without circle. If we focus on the mid-October period, we see a positive $\mathrm{CO}_{2}$ event both in model and observa- tions. The radon- 222 concentrations indicate a succession of continental air masses. The peaks are smoothed by the model due to the horizontal diffusion, but we find the same order of magnitude for radon-222 $\left(+180 \mathrm{mBq} \mathrm{m}^{-3}\right)$ and $\mathrm{CO}_{2}$ $(+1$ ppmv). The study of this event demonstrates a South Africa origin, equally distributed among industrial and biospheric fluxes. Then, in the same way that brought Cape Grim as an observatory of Australian fluxes, Amsterdam Island can be used as an observatory of regional fluxes from South Africa.

At the opposite of the previous example, the $\mathrm{CO}_{2}$ measurements at Amsterdam Island also display short term variations during low radon-222 periods, which implies an oceanic origin. Such a case, observed in June 1990, is represented on Fig. 11. Between 12-16 June 1990, baseline measurements indicate a strong decrease of about $1 \mathrm{ppmv}$. The decomposition of sources and sinks demonstrate the oceanic origin of this event. Furthermore, the backtrajectory indicate that the air mass came from the West and stayed more than 5 days in a narrow latitudinal band $\left(39^{\circ}-40^{\circ} \mathrm{S}\right)$, which correspond to the highest intensity of the Austral Oceanic sink in our fluxes distribution. A multi-year simulation would be necessary for an in-depth study of the synoptic events at Amsterdam Island and Cape Grim, because the periods of interest are relatively rare. 


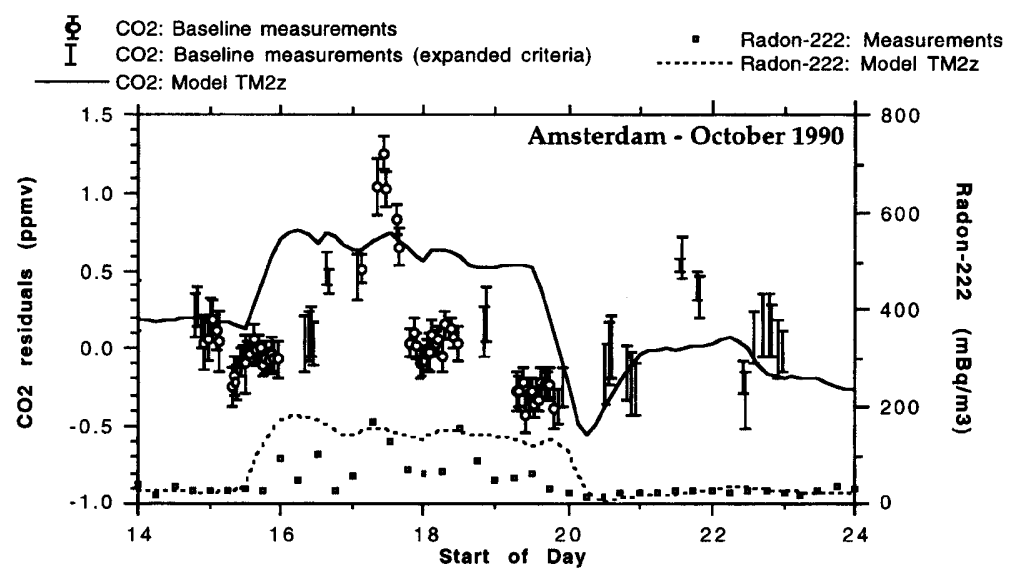

Fig. 10. $\mathrm{CO}_{2}$ (ppmv) and Radon-222 (mBq m$\left.{ }^{-3}\right)$ concentrations at Amsterdam Island in October 1990. Radon measurements are displayed with open squares, and Radon simulation with dashed line. The $\mathrm{CO}_{2}$ measurements are displayed with their hourly standard deviation. Baseline data according to the criteria defined by Gaudry et al. (1987) are represented with open circles. Other measurements were selected according to the stretched baseline as defined in the text. Simulated concentrations are figured with solid line.

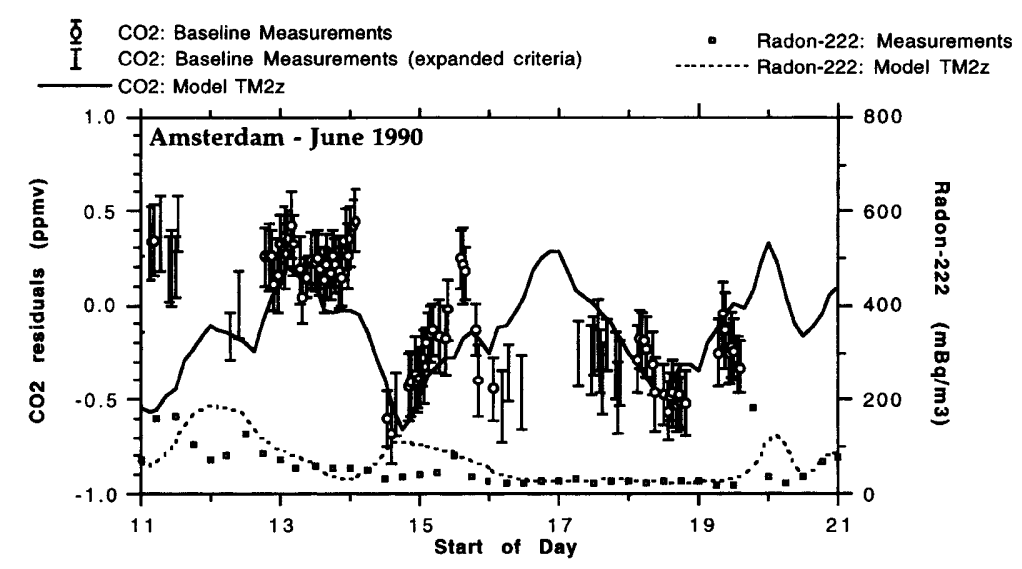

Fig. 11. Same as figure 10 for June 1990.

However the regional scale variations, intermediate between local and large scale ones, will be more and more instructive as the transport models will become more realistic, especially within PBL transport processes.

\section{Conclusions}

In this study, we developed the concept of baseline selection in 3-D transport models, and we quantified the effect of such a selection for two coastal stations (Cape Grim and Cape Meares), and one marine station (Amsterdam Island). The $\mathrm{CO}_{2}$ simulation was performed by using an highresolution transport model (TM2z) driven by the meteorological analyses from ECMWF for 1990, and a global distribution of $\mathrm{CO}_{2}$ sources and sinks based on the most recent dataset for industrial, biospheric, and oceanic fluxes.

Our results demonstrate the necessity for a baseline selection of the simulated concentrations in coastal and marine stations. We compared the efficiency of several methods to select the baseline periods. The best results are obtained when we took into account some information about the 
atmospheric transport during the last 5 days, which is enough to be representative of the regional transport (i.e., a few thousands of kilometers). To do so, we used 5-days back-trajectories, and the simulated concentrations of radon- 222 . For the latter method, a threshold of $500 \mathrm{mBq} \mathrm{m}^{-3}$ allows a good selection of the baseline periods for the 2 coastal stations. The suppression of the non baseline events induced in these two sites a decrease of $30 \%$ on the annual peak to peak amplitude, and a decrease by a factor of three on the synoptic scale variability averaged over the year. The model selection induces also a shift of the seasonal phase by about one month and half at Cape Grim. All these modifications allow a highly improved comparison between measurements and results of simulation. Furthermore, implementing baseline selections in the transport model can induce a shift of some tenths of ppmv of the simulated annual means at coastal stations. For remote marine station, like Amsterdam Island, the baseline selection was shown to be less critical. However, the use of backtrajectories induced a correction of the monthly means up to $0.3 \mathrm{ppmv}$, and consequently a better representation of the non sinusoidal shape of the seasonal cycle at Amsterdam. By neglecting the baseline selection in the model, we would erroneously interpret such differences between observations and simulations as errors in either atmospheric transport, or $\mathrm{CO}_{2}$ fluxes.

It is worth noting that the transport models clearly develop toward more refined resolutions and transport parameterizations. So the synoptic scale variations will be more accurately resolved, and consequently (1) the baseline selection in transport models, as described above, will have a more pronounced effect and it can no longer be overlook; (2) it will be possible to relate some of the non baseline variations to the regional fluxes. As a preliminary study, we have pointed out the potential interest of some data which are rejected since they do not satisfy the baseline criteria. For instance, the Cape Grim and Amsterdam stations were seen as potential observatories of the $\mathrm{CO}_{2}$ fluxes over Australia and South Africa. Even if the TM $2 z$ was able to simulate synoptic scale variations originated from these continents, the coarse vertical resolution of this model was seen as a major limitation to simulate the diurnal variations of $\mathrm{CO}_{2}$.

\section{Acknowledgments}

The provisional $\mathrm{CO}_{2}$ data from the Baseline Air Pollution Station at Cape Grim, Tasmania, which have been used in this study, were supplied by D.J. Bearsdmore and G.I. Pearman of the CSIRO Division of Atmospheric Research, Australia. We acknowledge the Carbon Cycle Group at CMDL/NOAA for providing $\mathrm{CO}_{2}$ measurements at Cape Meares, Oregon. We acknowledge computing support from CEA/LMCE, and from CCVR/IDRIS. Our sincere thanks to Y. Balkanski, C. Lambert, P. Ciais, A. Gaudry, and two anonymous reviewers whose suggestions helped to improve the paper. This work is supported by the Programme National d'Etude de la Dynamique du Climat, the Institut Français pour la Recherche et la Technologie Polaires and the Comission of European Community program Environment CEE EV5V CT92-0120. This is CFR contribution no. 1760.

\section{REFERENCES}

Bakwin, P. S., Tans, P. P., Zhao C., Ussler, W. and Quesnell, E. 1995. Measurements of carbon dioxide on a very tall tower. Tellus 47B, 535-549.

Beardsmore, D. J. and Pearman, G. I. 1987. Atmospheric carbon dioxide measurements in the Australian region: data from surface observations. Tellus 39B, 42-66.

Ciais, P., Tans, P. P., White, J. W. C., Trolier, M., Francey, R. J., Berry, J. A., Randall, D. R., Sellers, P. J., Collatz, J. G. and Schimel, D. S. 1995. Partitioning of ocean and land uptake of $\mathrm{CO}_{2}$ as inferred by $\delta 13 \mathrm{C}$ measurements from the NOAA/CMDL global air sampling network. J. Geophys. Res. 100, 5051-5070.

Conway, T. J., Tans, P. P., Waterman, L. S., Thoning,
K. W., Kitzis, D. R., Masarie, K. A. and Zhang, N. 1994a. Evidence for interannual variability of the carbon cycle from the National Oceanic and Atmospheric Administration/Climate Monitoring and Diagnostics Laboratory Global Air Sampling Network. J. Geophys. Res. 99, 22831-22855.

Conway, T. J., Tans, P. P. and Waterman, L. S., 1994b. Atmospheric $\mathrm{CO}_{2}$ records from sites in the NOAA/ CMDL air sampling network. Trends '93: A compendium of data on global change ed.: T. A. Boden, D. P. Kaiser, R. J. Sepanski and F. W. Stoss, ORNL/ CDIAC-65, Oak Ridge, Tenn, USA, 41-119.

Denning, S. A. 1995. Latitudinal gradient of atmospheric 
$\mathrm{CO}_{2}$ due to seasonal exchange with land biota. Nature 376, 240-243.

Enting, I. G. 1989. Studies of baseline criteria for CapeGrim, Tasmania. Environ. Res. Lab. Boulder, Colo. ERL-ARL-173, 51-60.

Enting, I. G. and Mandsbridge, J. V. 1989. Seasonal sources and sinks of atmospheric $\mathrm{CO}_{2}$ : direct inversion of filtered data. Tellus 41B, 111-126.

Enting, I. G. and Mansbridge, J. V. 1991. Latitudinal distribution of sources and sinks of $\mathrm{CO}_{2}$ : results of an inversion study. Tellus 43B, 156-170.

Enting, I. G. and Pearman, G. I. 1993. Average global distributions of $\mathrm{CO}_{2}$. The global carbon cycle, ed.: $\mathrm{M}$. Heimann. NATO ASI Series, 31-64.

Enting, I. G. and Trudinger, C. M. 1990. Modeling studies of small-scale variability in atmospheric $\mathrm{CO}_{2}$. Baseline atmospheric program (Australia), ed.: G. J. L. Wilson S. R. Bureau of Meteorology and CSIRO/ DAR, Melbourne, 10-16.

Enting, I. G., Trudinger, C. M., Francey, R. J. and Granek, H. 1993. Synthesis inversion of atmospheric $\mathrm{CO}_{2}$ using the GISS tracer transport model. CSIRO. Division of Atmospheric Research Tech. Paper No 29, $44 \mathrm{pp}$.

Erickson III, D. J., Rasch, P. J., Tans, P. P., Friedlingstein P., Ciais,. P., Maier-Reimer, E., Six, K., Fisher, C. A. and Walters, S. 1996. The seasonal cycle of atmospheric $\mathrm{CO}_{2}$ : a study based on the NCAR Community Climate Model (CCM2). J. Geophys. Res. 101, 15079-15097.

Fung, I. Y., Tucker, C. J. and Prentice, K. C. 1987. Application of advanced very high resolution radiometer vegetation index to study atmosphere-biosphere exchange of $\mathrm{CO}_{2}$. J. Geophys. Res. 92, 2999-3015.

Gaudry, A., Ascencio, J. M. and Lambert, G. 1983. Preliminary study of $\mathrm{CO}_{2}$ Variations at Amsterdam Island (Territoires des Terres Australes et Antarctiques Françaises). J. Geophys. Res. 88, 1323-1329.

Gaudry, A., Monfray, P., Polian, G. and Lambert, G. 1987. The 1982-83 El-Niño: a 6 billion ton $\mathrm{CO}_{2}$ release. Tellus 39B, 209-213.

Gaudry, A., Monfray, P., Polian, G. and Lambert, G. 1990. Radon-calibrated emissions of $\mathrm{CO}_{2}$ from South Africa. Tellus 42B, 9-19.

Heimann, M. 1995. The global atmospheric tracer model TM2. Tech. Report No. 10, ed. by Deutsches Klimarechenzentrum, Hamburg, 51 pp.

Heimann, M., Monfray, P. and Polian, G. 1990. Modeling the long-range transport of ${ }^{222} \mathrm{Rn}$ to subantarctic and antarctic areas. Tellus. 42B, 83-99.

Heimann, M., Keeling C. D. and Tucker, C. J. 1989a. A three dimensional transport model for atmospheric $\mathrm{CO}_{2}$ (3) Seasonnal cycle and synoptic time scale variations. Geophysical Monograph 55. Aspects of climate variability in the Pacific and the Western Americas, ed.: D. H. Peterson. AGU, Washington, USA, 277-303.

Heimann, M. and Keeling, C. D. 1989b. A threedimensional transport model for atmospheric $\mathrm{CO}_{2}(2)$
Model description and simulated tracer experiments. Geophysical Monograph 55, Aspects of climate variability in the Pacific and the Western Americas, ed.: D. H. Peterson. AGU, Washington, USA, 237-275.

Keeling, C. D., Piper, S. C. and Heimann, M. 1989. A three-dimensional transport model for atmospheric $\mathrm{CO}_{2}$ (4) Mean annual gradients and interannual variations. Geophysical Monograph 55, Aspects of climate variability in the Pacific and the Western Americas, ed.: D. H. Peterson. AGU, Washington USA, 305-363.

Lambert, G., Polian, G., Sanak, J., Ardouin, B., Buisson, A., Jegou, A. and Le Roulley, J. C. 1982. Cycle du radon et de ses descendants: application à l'étude des échanges troposphère-stratosphère. Ann. Geophys. 38, 497-531.

Liss, P. S. and Merlivat, L. 1986. Air-sea gas exchange rates: introduction and synthesis. The role of air-sea exchange in geochemical cycling, ed.: P. Buat-Menard., Adv. Sci. Inst. Ser., D. Reidel Pub. Co., 113-127.

Liu, S. C., Mc Affee, J. R. and Cicerone, R. J. 1984. Radon-222 and tropospheric vertical transport. J. Geophys. Res. 89, 7291-7297.

Louis, J. F. 1979. A parametric model of vertical eddy fluxes in the atmosphere. Boundary Layer Met. 17, 187-202.

Manning, M. R. 1993. Seasonal cycles in atmospheric $\mathrm{CO}_{2}$ concentrations. The global carbon cycle, (ed. M. Heimann). NATO ASI Series, 65-94.

Metzl, N., Poisson, A., Louanchi, F., Brunet, C., Schauer, B. and Bres, B. 1995. Spatio-temporal distributions of air-sea fluxes of $\mathrm{CO}_{2}$ in the Indian and Antarctic oceans. A first step, Tellus. 47B, 56-69.

Monfray, P., Ramonet, M. and Beardsmore, D. J., 1996. Longitudinal and vertical gradient over the subtropical/subantarctic oceanic $\mathrm{CO}_{2}$ sink. Tellus $48 \mathrm{~B}$, this issue.

Poisson, A., Metzl, N., Brunet, C., Schauer, B., Bres, B., Ruiz-Pino, D. and Louanchi, F. 1993. Variability of sources and sinks of $\mathrm{CO}_{2}$ in the western Indian and southern oceans during the year 1991. J. Geophys. Res. 98, 22759-22778.

Polian, G., Lambert, G., Ardouin, B. and Jegou, A. 1986. Long-range transport of continental radon in subantarctic and antarctic areas. Tellus 38B, 178-189.

Ramonet, M. 1994. Variabilité du $\mathrm{CO}_{2}$ atmosphérique en régions australes: comparaison modèle-mesures. Thesis. University of Paris 7, 295 pp.

Ramonet, M., Le Roulley, J. C., Bousquet, P. and Monfray, P. 1996. Radon-222 measurements during the TROPOZ II campaign and comparison with a global atmospheric transport model, J. Atmos. Chem. 23, 107-136.

Rayner, P. J. and Law, R. M. 1995. A comparison of modeled responses to prescribed $\mathrm{CO}_{2}$ sources. CSIRO, Division of Atmospheric Research. Tech. Paper No. 36, $84 \mathrm{pp}$.

Ruimy, A., Dedieu, G. and Saugier, B. 1994. Methodology for the estimation of terrestrial net primary pro- 
duction from remotely sensed data. J. Geophys. Res. 99, 5263-5283.

Tanaka, M., Nakazawa, T., Shiobara, M., Ohshima, H. and Aoki, S. 1987. Variations of atmospheric carbon dioxide concentration at Syowa station $\left(69^{\circ} 00^{\circ} \mathrm{S}, 39^{\circ} 35^{\prime} \mathrm{E}\right)$, Antarctic. Tellus 39B, 72-79.

Tans, P. P., Conway, T. J. and Nakazawa, T. 1989. Latitudinal distribution of the sources and sinks of atmospheric carbon dioxide derived from surface observations and an atmospheric transport model. J. Geophys. Res. 94, 5151-5172.

Tans, P. P., Fung, I. Y. and Takahashi, T. 1990. Observational constraints on the global atmospheric $\mathrm{CO}_{2}$ budget. Science 247, 1431-1438.

Tiedtke, M. 1989. A comprehensive mass flux scheme for cumulus parameterization in large-scale models. Mon. Weather Rev. 117, 1779-1800.
Weiss, R. F., Van Woy, F. A. and Salameh, P. K. 1992. Surface water and atmospheric carbon dioxide and nitrous oxide observations by shipboard automated gas chromatography: results from expeditions between 1977 and 1990. Carbon Dioxide Information Analysis Center. Oak Ridge National Laboratory, Oak Ridge.

Whittlestone, S. 1991. Radon as baseline selection criteria at Mauna Loa Observatory. CMDL, Summary Report 1990, ed.: E. E. Ferguson and R. M. Rosson, pp. $120-123$.

WMO/WDCGG, 1992. Part A: Carbon dioxide, Greenhouse gases and other atmospheric gases. ed.: The Japan Meteorological Agency in cooperation with the WMO, Report No 2, 776 pp.

Wofsy, S. C., Goulden, M. L., Munger, J. W., Fan, S. M., Bakwin, P. S., Daube, B. C., Bassow, S. L. and Bazzaz, F. A. 1993. Net Exchange of $\mathrm{CO}_{2}$ in a mid-latitude forest. Science 260, 1314-1317. 